\title{
Aquapteridospora Jiangxiensis sp. Nov., A New Aquatic Hyphomycetes From Freshwater Habitats in China and $\boldsymbol{A}$. Bambusinum Comb. Nov.
}

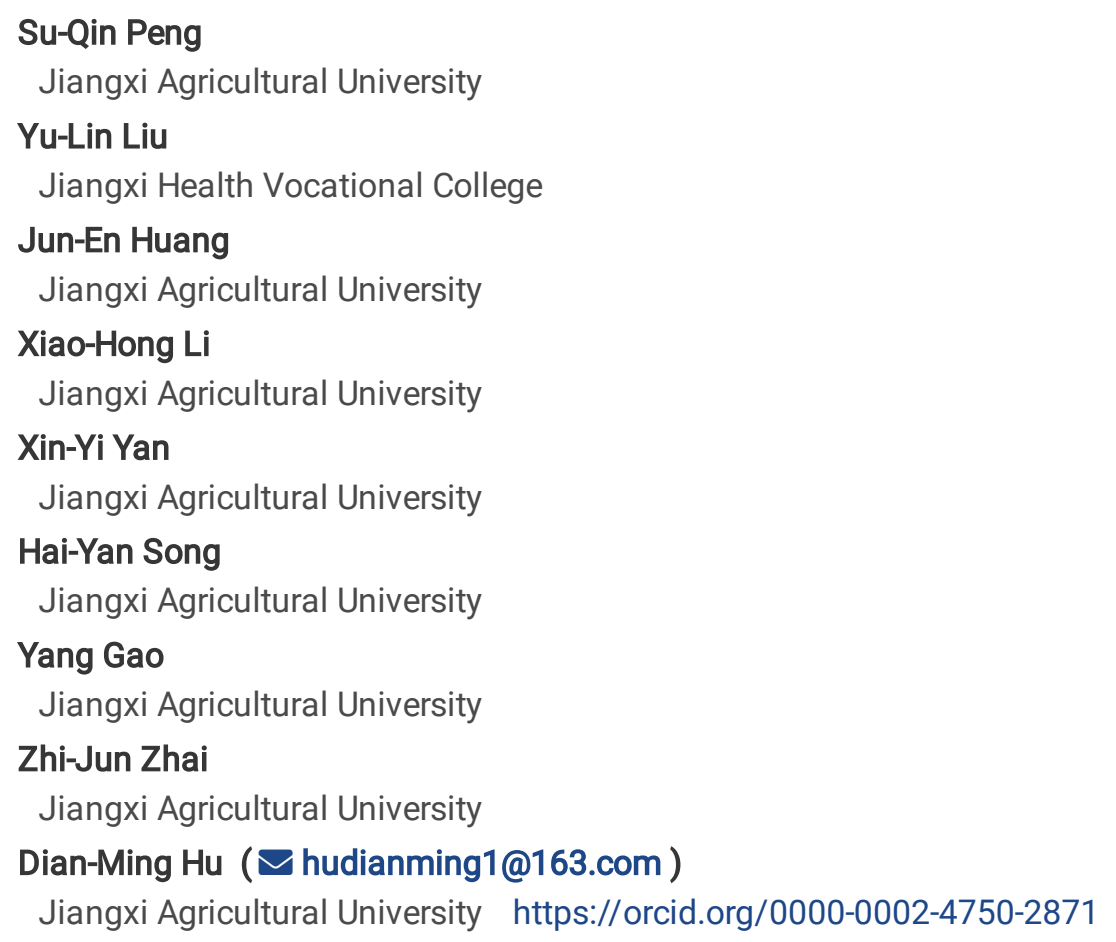

\section{Research Article}

Keywords: hyphomycetes, freshwater fungi, Ascomycota, taxonomy

Posted Date: October 18th, 2021

DOI: https://doi.org/10.21203/rs.3.rs-967372/v1

License: (1) This work is licensed under a Creative Commons Attribution 4.0 International License. Read Full License 


\section{Abstract}

During an investigation of freshwater fungi in Jiangxi province, China, a new hyphomycetous species, Aquapteridospora jiangxiensis, was collected and isolated. A. jiangxiensis is characterized by its unbranched and guttulate conidiophores with multisepta and swollen at the base, polyblastic conidiogenous cells with sympodial proliferations and denticles, guttulate conidia with a sheath. The new species was illustrated and a muti-loci (ITS, LSU, SSU, TEF1 and RPB2) phylogenetic tree was constructed. Pleurophragmium bambusinum was is transferred to Aquapteridospora based on molecular and morphological data. A key to the species of Aquapteridospora is presented in this paper.

\section{Introduction}

Yang et al. (2015) established the genus Aquapteridospora with A. lignicola Jiao Yang, K.D. Hyde \& Maharachch as the type species, which was collected from a freshwater stream in northern Thailand. Aquapteridospora is characterized by its polyblastic conidiogenous cells with several sympodial proliferations, bearing tiny, protuberant, circular scars and fusiform conidia, with pale to dark brown central cells and subhyaline end cells, sometimes with a conspicuous sheath (Yang et al. 2015). Currently, there are three species belonging to the genus Aquapteridospora, i.e. A. aquatica X.D. Yu, W. Dong \& H. Zhang, A. fusiformis Z.L. Luo, D.F. Bao, H.Y. Su \& K.D. Hyde and A. lignicola (Luo et al. 2019; Dong et al. 2021).

Aquapteridospora is a typical freshwater genus, and all the known species of this genus were reported from freshwater habitats (Yang et al. 2015; Luo et al. 2019; Dong et al. 2021). We have been investigated the freshwater fungi in China for 20 years (Hu et al. 2007; Huang et al. 2016; Hu et al. 2017; Song et al. 2018a; Song et al. 2018b; Song et al. 2020a; Song et al. 2020b). When investigating the fungal diversity in a small stream in Jiangxi Province, China, a hyphomycetous fungus was collected. The fungus resembles species of Aquapteridospora. After a comprehensive study on its morphological characters and molecular phylogeny, we confirmed that the fungus was a new species of Aquapteridospora. Therefore, we describe the fungus as a new species in this paper.

\section{Materials \& Methods}

\section{Sample collection, fungal isolation and morphological studies}

Unidentified wood samples submerged in a freshwater stream were collected in Jiangxi Province, China, and incubated in moist chambers at room temperature (ca. $25^{\circ} \mathrm{C}$ ). Samples were examined for fungal fruiting bodies using a dissecting microscope once a week. The spores from the fruiting bodies were diluted and dropped on plates with potato dextrose agar (PDA) medium. After incubating in room temperature for 12 hours, the germinated spores were picked up and incubated in a new PDA plate to obtain pure cultures. Observations and photographs were prepared from materials mounted in water and examined with a Nikon Ni compound microscope (Hu et al. 2012a). The specimens examined were deposited in the Herbarium of Fungi, Jiangxi Agricultural University, Nanchang, China (HFJAU), and the living cultures were deposited in the Culture Collection of Jiangxi Agricultural University (JAUCC) and Dr. Lei Cai's personsal collection (LC).

\section{Dna Extraction, Gene Amplification, Sequencing, And Phylogentic Analyses}

Genomic DNA was extracted from fungal mycelia using CTAB method following the instruction described by Wu et al (2001). We amplified five nuclear DNA sequences. ITS (internal transcribed spacer) sequences were amplified with primers ITS4 and ITS5 (White et al. 1990). Partial sequences of LSU (large subunit ribosomal RNA) genes were amplified with primers LROR and LR6 (Vilgalys and Hester 1990; Rehner and Samuels 1995). Partial sequences of SSU (small subunit ribosomal RNA) genes were amplified with primers NS1 \& NS4 (White et al. 1990). Partial sequences of TEF1 (translation elongation factor EF-1 alpha) genes were amplified with primers EF1-983F and EF1-2218R (Rehner 2001). Partial sequences of RPB2 (RNA polymerase II second largest subunt) genes were amplified with primers fRPB2-5F and fRPB20-7CR (Liu et al. 1999). PCR protocols followed the 
conditions set by Hu et al (2012b). The PCR products were purified and sequenced by the same primers used for PCR at Tsingke Biotechnology Co., Ltd.

In this study, we generated five novel sequences (MZ871502, MZ871501, MZ855767, MZ855768, MZ855769) and retrieved 41 reference sequences from GenBank (Table 1) that were aligned using MAFFT v.7 (Katoh and Standley 2013). 
Table 1

Reference strains used in this study and their GenBank numbers.

\begin{tabular}{|c|c|c|c|c|c|c|}
\hline \multirow[t]{2}{*}{ Species } & \multirow{2}{*}{$\begin{array}{l}\text { Strain } \\
\text { number }\end{array}$} & \multicolumn{5}{|c|}{ Genbank number } \\
\hline & & ITS & LSU & SSU & TEF1 & RPB2 \\
\hline Pleurophragmium acutum & $\begin{array}{l}\text { CBS } \\
129113\end{array}$ & MH865210 & MH876650 & & & \\
\hline Pleurophragmium bambusinum & $\begin{array}{l}\text { MFLUCC } \\
12-0850\end{array}$ & KU940161 & KU863149 & & KU940213 & \\
\hline Aquapteridospora aquatica & $\begin{array}{l}\text { MFLUCC } \\
17-2371\end{array}$ & MW286493 & MW287767 & & & \\
\hline Aquapteridospora jiangxiensis * & $\begin{array}{l}\text { JAUCC } \\
3008\end{array}$ & MZ871502 & MZ871501 & & MZ855767 & MZ855768 \\
\hline Aquapteridospora lignicola & $\begin{array}{l}\text { MFLU 15- } \\
1172\end{array}$ & & KU221018 & & & \\
\hline Aquapteridospora fusiformis & $\begin{array}{l}\text { MFLU 18- } \\
1601\end{array}$ & MK828652 & MK849798 & & MN194056 & \\
\hline Junewangia aquatica & HFJAU0700 & MG213738 & MG213737 & MG213736 & & \\
\hline Junewangia globulosa & $\begin{array}{l}\text { CBS } \\
126093\end{array}$ & MH864078 & MH875535 & & & \\
\hline Junewangia thailandica & $\begin{array}{l}\text { MFLU 15- } \\
2682\end{array}$ & & MW287762 & & & \\
\hline Junewangia lamma & $\begin{array}{l}\text { HMAS } \\
44438\end{array}$ & KU999961 & KU751882 & KX033523 & & \\
\hline Junewangia lamma & $\begin{array}{l}\text { HSAUP } \\
\text { H4695 }\end{array}$ & KU999971 & KU751883 & KX033533 & & \\
\hline Junewangia sphaerospora & $\begin{array}{l}\text { HSAUP } \\
\text { myr4733 }\end{array}$ & KU999981 & KX033572 & KX033543 & & \\
\hline Junewangia queenslandic & $\begin{array}{l}\text { HSAUP } \\
\text { myr7722 }\end{array}$ & KU999984 & KX033575 & KX033546 & & \\
\hline Diluviicola aquatica & $\begin{array}{l}\text { MFLUCC } \\
15-0986\end{array}$ & MF374356 & MF374365 & & MF370961 & MF370953 \\
\hline Dictyosporella hydei & $\begin{array}{l}\text { IFRDCC } \\
3075\end{array}$ & & MG813161 & & & \\
\hline Dictyosporella guizhouensis & $\begin{array}{l}\text { MFLUCC } \\
18-1232\end{array}$ & MW286487 & MW287760 & & MW396646 & \\
\hline Dictyosporella guizhouensis & $\begin{array}{l}\text { MFLU 18- } \\
1505\end{array}$ & MK593606 & MK593605 & MK593611 & & \\
\hline Dictyosporella aquatica & S-777 & MK828692 & MK849843 & & & \\
\hline Dictyosporella aquatica & $\begin{array}{l}\text { CBS H- } \\
22127\end{array}$ & & KT241022 & KT241023 & & \\
\hline Dictyosporella thailandensis & $\begin{array}{l}\text { MFLUCC } \\
15-0985\end{array}$ & MF374355 & MF374364 & MF374373 & MF370958 & MF370952 \\
\hline Dictyosporella chiangmaiensis & $\begin{array}{l}\text { MFLUCC } \\
17-2345\end{array}$ & MW286491 & MW287765 & & & \\
\hline Sporidesmiella hyalosperma & $\begin{array}{l}\text { KUMCC 15- } \\
0431\end{array}$ & MK828690 & MK849841 & MK828306 & & \\
\hline
\end{tabular}

Remarks: Species name given in bold denote ex-type strains. "*" denotes the new species. 


\begin{tabular}{|c|c|c|c|c|c|c|}
\hline \multirow[t]{2}{*}{ Species } & \multirow{2}{*}{$\begin{array}{l}\text { Strain } \\
\text { number }\end{array}$} & \multicolumn{5}{|c|}{ Genbank number } \\
\hline & & ITS & LSU & SSU & TEF1 & RPB2 \\
\hline Sporidesmiella hyalosperma & $\begin{array}{l}\text { MFLUCC } \\
18-1013\end{array}$ & MW286499 & MW287773 & & MW396654 & MW504070 \\
\hline Sporidesmiella hyalosperma & $\begin{array}{l}\text { MFLUCC } \\
18-1312\end{array}$ & MK828688 & MK849839 & & & \\
\hline Sporidesmiella obovoidia & $\begin{array}{l}\text { MFLUCC } \\
17-2372\end{array}$ & MW286492 & MW287766 & & & \\
\hline Sporidesmiella novae-zelandiae & S-951 & MK828695 & MK849847 & & & \\
\hline Sporidesmiella novae-zelandiae & S-1256 & MK828693 & MK849845 & & & \\
\hline Sporidesmium dulongense & $\begin{array}{l}\text { MFLUCC } \\
17-0116\end{array}$ & MH795812 & MH795817 & & & \\
\hline Sporidesmium lageniforme & $\begin{array}{l}\text { MFLU 18- } \\
1594\end{array}$ & MK828640 & MK849782 & & MN194044 & MN124533 \\
\hline Sporidesmium thailandense & $\begin{array}{l}\text { MFLUCC } \\
15-0964\end{array}$ & MF374361 & MF374370 & & MF370957 & MF370955 \\
\hline Sporidesmium pyriformatum & $\begin{array}{l}\text { MFLUCC } \\
15-0627\end{array}$ & KX710148 & KX710143 & & MF135663 & \\
\hline Sporidesmium pyriformatum & $\begin{array}{l}\text { MFLUCC } \\
15-0620\end{array}$ & KX710146 & KX710141 & & MF135662 & MF135649 \\
\hline Sporidesmium chiangmaiense & $\begin{array}{l}\text { MFLUCC } \\
18-0999\end{array}$ & MW286497 & MW287771 & & & \\
\hline Sporidesmium appendiculatum & $\begin{array}{l}\text { MFLU 18- } \\
0981\end{array}$ & MW286500 & MW287774 & & & \\
\hline Sporidesmium melaleucae & CPC 32936 & МH327818 & MH327854 & & & \\
\hline Sporidesmium melaleucae & СРC 32707 & MH327817 & MH327853 & & & \\
\hline Longicollum biappendiculatum & PE0017-1a & KU975062 & KU975071 & & & \\
\hline Pseudoproboscispora caudae-suis & CBS 146.51 & MH856788 & MH868307 & & & \\
\hline Pseudoproboscispora thailandensis & $\begin{array}{l}\text { MFLUCC } \\
15-0989\end{array}$ & MF374360 & MF374369 & MF374377 & MF370959 & \\
\hline Jennwenomyces navicularis & NCYU-JW1 & MT224911 & MT224910 & & & \\
\hline Cateractispora recepticuli & $\begin{array}{l}\text { HKUCC } \\
3710\end{array}$ & & AF132327 & & & \\
\hline Dothidea insculpta & CBS 189.58 & AF027764 & DQ247802 & DQ247810 & & \\
\hline
\end{tabular}

The ML analyses were functioned with RAxML v7.2.6 (Stamatakis and Alachiotis 2010) using a GTRGAMMA substitution model with 1000 bootstrap replicates and evaluated by bootstrap support (MLBS). Trees were sampled 100 generations and the first $25 \%$ deleted as burn-in trees. Four simultaneous Markov chains were run 2,000,000 generations, resulting a total of 40002 trees (sampling 30002 of them). Posterior probabilities values of the BI analyses (BPP) over 0.95 were showed on the tree. The novel taxonomic descriptions and nomenclature were deposited in MycoBank (http://www.mycobank.org/).

\section{Result}

\section{Phylogenetic analysis}


The phylogenetic tree based on the five-locus analysis (Fig. 1) shows the relationship between the new species and other related taxa. The dataset including alignment gaps comprised 4415 characters: 646 for ITS, 843 for LSU, 999 for SSU, 873 for TEF1 and 1054 for RPB2. Branchs support of MLBS $\geq 70 \%$ and PP value $\geq 0.90$ are indicated above branches. The tree is rooted to Dothidea insculpta CBS 189.58. The new species Aquapteridospora jiangxiensis JAUCC3008 together with other Aquapteridospora species formed a well-supported clade (BPP $=1$, MLBS $=100 \%$ ).

\section{Taxonomy}

Aquapteridospora jiangxiensis J.E. Huang, H.Y. Song \& D.M. Hu, sp. nov.

Mycobank No: 841242

Etymology. In reference to the host location, Jiangxi province, where the holotype was collected.

Holotype: HFJAU 3176

Saprobic on decaying submerged wood. Sexual morph Undetermined. Asexual morph Hyphomycetous. Colonies effuse consisting of conidiophores scattered over the substrate surface, brown to dark brown. Mycelium septate, hyaline, partly

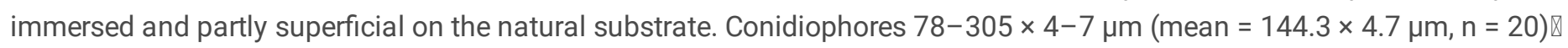
macronematous, mononematous, cylindrical, erect, usually straight or slightly flexuous and sometimes flexuous, smooth, 3-15septate, unbranched, dark brown in the middle and below, pale brown above, thick-walled, with abundant small guttulae, occasionally slight swollen at the base. Conidiogenous cells polyblastic, 20-68 $\times 4-6 \mu \mathrm{m}$ (mean $=41.2 \times 4.8 \mu \mathrm{m}, \mathrm{n}=20$ ), integrated, terminal, becoming intercalary, pale brown to brown, smooth, subclavate to subcylindrical, with several sympodial proliferations, bearing some conspicuous, rounded, brown to mid-brown denticles. Conidia 20-25 $\times 6-7.5 \mu \mathrm{m}$ (mean $=22.5 \times 6.5$ $\mu \mathrm{m}, \mathrm{n}=25) \mu \mathrm{m}$, acrogenous or lateral, fusiform to subclavate, rounded at the apex, base truncate, $0.9-1.5 \mu \mathrm{m}$ wide, straight to slightly curved, 3-septate, slightly constricted at septa and septa dark brown to black, with mid to dark brown central cells and pale to mid brown end cells, with abundant small guttulae, smooth-walled, sometimes with a sheath.

Culture characteristics: Conidia germinating on PDA within $24 \mathrm{~h}$. Colonies growing on PDA, circular, reaching 40-60 mm diam. after 2-3 weeks at $28^{\circ} \mathrm{C}$; from above, flat, center grey-white with some dark brown spots and edge dark brown, mycelium superficial to immersed in media; from below, center grey-brown, near the edge black, with smooth margin.

Material examined: CHINA, Jiangxi Province, Shangrao, Dexing, Xiangtun Street, on submerged wood in a stream, 12 August 2018, J.E. Huang (Holotype, HFJAU 3176); ex-type living culture (JAUCC 3008).

Notes: The phylogenetic analysis based on combined data of ITS, LSU, SSU, TEF1 and RPB2 sequences showed that Aquapteridospora jiangxiensis clusters within Aquapteridospora clade with high bootstrap support (Fig. 1). Morphologically, $A$. jiangxiensis is characterized by its unbranched and guttulate conidiophores with multi-septa and swollen at the base, polyblastic conidiogenous cells with sympodial proliferations and denticles, guttulate conidia with a sheath, which fits well with the concepts of the genus Aquapteridospora (Yang et al. 2015). Aquapteridospora jiangxiensis shows obvious distrance to the other species of Aquapteridospora in the phylogenetic tree (Fig. 1). Morphologically, A. jiangxiensis differs from the other four species of Aquapteridospora by its fusiform to subclavate conidia with rounded apex and truncate base.

\section{Aquapteridospora bambusinum (D.Q. Dai \& K.D. Hyde) J.E. Huang, H.Y. Song \& D.M. Hu, comb. nov.}

Mycobank No: 841243

三Pleurophragmium bambusinum D.Q. Dai \& K.D. Hyde, in Dai, Phookamsak, Wijayawardene, Li, Bhat, Xu, Taylor, Hyde \& Chukeatirote, Fungal Diversity 82: 90 (2017).

Notes: Pleurophragmium bambusicola is characterized by polyblastic, sympodial, denticulate conidiogenous cells and 3-septate, brown, thick-walled conida (Dai et al. 2017), which fit the generic concepts of Aquapteridospora (Yang et al. 2015). On the phylogenetic tree (Fig 1), the type strain (MFLUCC 12-0805) of Pleurophragmium bambusicola clusters within Aquapteridospora 
clade with high bootstrap support (BPP $=1, \mathrm{MLBS}=100 \%)$. Therefore, we transfer Pleurophragmium bambusicola to the genus Aquapteridospora.

\section{Discussion}

Aquapteridospora is described herein as a monotypic by Yang et al (2015). The type species A. lignicola resembles Minimelanolocus manifestus Hern.-Restr., R.F. Castañeda, Gené \& Guarro, however M. manifestus has cymbiform to subfusiform conidia, which are fimbrillate at the base and lacks a sheath (Hernández-Restrepo et al. 2012; Yang et al. 2015). Aquapteridospora lignicola also resembles Pleurophragmium indicum M.A. D'Souza \& Bhat., however $P$. indicum has ellipsoidal to obovoid conidia, with dark brown central cells and pale brown end cells and lacks a sheath (D'Souza and Bhat 2012; Yang et al. 2015). Molecular phylogenetic analysis is very important in inferring the taxonomic placement of hyphomycetous fungi. Yang et al (2015) conducted a molecular phylogeny of Aquapteridospora based on LSU sequences, and confirmed its phylogentic placement confirmed in Diaporthomycetidae genera incertae sedis. Recently, Dong et al (2021) conducted a molecular phylogeny study based on combined LSU, ITS, TEF and RPB2 sequences data, and established a new family Aquapteridosporaceae K.D. Hyde \& Hongsanan (Distoseptisporales Z.L. Luo, K.D. Hyde \& H.Y. Su) to accommodate a single genus Aquapteridospora (Hyde et al. 2021).

Five speces are accepted in Aquapteridospora in these paper, including the new species and new combination proposed in this tudy. A key to the five species of Aquapteridospora is presented.

\section{Key to Aquapteridospora species}

1. Conidia without sheath................................................................2

1. Conidia with sheath . .3

2. Conidia ellipsoidal, equally coloured, thick-walled, 13-21 × 5-7 $\mu \mathrm{m}$...A. bambusinum

2. Conidia fusiform, obtuse at both ends, brown to dark brown in central cells and subhyaline at end cells, $14-18 \times 5-7$ $\mu \mathrm{m}$ A. fusiformis

3. Conidia obtuse at both ends, $15-24 \times 6-8 \mu \mathrm{m}$ A. lignicola

3. Conidia not obtuse at both ends 4

4. Conidia fusiform, slightly tapering towards the apex, 19-27.5 × 5-7.5 .. A. aquatica

4. Conidia fusiform to subclavate, rounded at the apex, base truncate, $20-25 \times 6-7.5$ $\mu \mathrm{m}$ A. jiangxiensis

\section{Declarations}

The authors declare that there are not conflicts of interest.

\section{Acknowledgments}

Funds for research were provided by the National Natural Science Foundation of China (NSFC 32070023 and NSFC 32060014), the Key Projects of Youth Fund of Jiangxi Science and Technology Department of China (20192ACBL21017), Natural Science Foundation of Education Department of Jiangxi Province of China (GJJ190168).

\section{References}

1. D'Souza MA, Bhat DJ (2012) A new species of Pleurophragmium from India. Mycotaxon 119:477-482

2. Dai DQ et al (2017) Bambusicolous fungi. Fungal Divers 82:1-105 i: 10.1007/s13225-016-0367-8 (. : do

3. Dong W et al (2021) Towards a natural classification of annulatascaceae-like taxa II: introducing five new genera and eighteen new species from freshwater. Mycosphere 12:1-88. doi:10.5943/mycosphere/12/1/1

4. Hernández-Restrepo M, Castañeda-Ruiz RF, Gené J, Guarro J, Minter DW, Stadler M (2012) Microfungi from Portugal: Minimelanolocus manifestus sp. nov. and Vermiculariopsiella pediculata comb. nov. Mycotaxon 122:135-143

Page $7 / 10$ 
5. Hu DM, Cai L, Bahkali AH, Hyde KD (2012a) Two new freshwater species of Annulatascaceae from China. Mycotaxon 120:81-88. doi:10.5248/120.81

6. Hu DM, Cai L, Hyde KD (2012b) Three new ascomycetes from freshwater in China. Mycologia 104:1478-1489. doi:10.3852/11-430

7. Hu DM, Wang M, Cai L (2017) Phylogenetic assessment and taxonomic revision of Mariannaea. Mycological Progress 16:271-283. doi:10.1007/s11557-016-1252-2

8. Hu DM, Zhu H, Cai L, Hyde KD, Zhang KQ (2007) Sirothecium triseriale, a new chirosporous anamorphic species from China. Cryptogamie Mycologie 28:311-314

9. Huang J-E, Song H-Y, Ma J, Guan G-X, Hu D-M (2016) Xylohyphopsis aquatica sp. nov., a new aquatic hyphomycete from China. Mycotaxon 131:391-394. doi:10.5248/131.391

10. Hyde KD, Bao D-F, Hongsanan S, Chethana KWT, Yang J, Suwannarach N (2021) Evolution of freshwater Diaporthomycetidae (Sordariomycetes) provides evidence for five new orders and six new families. Fungal Divers 107:71-105. doi:10.1007/s13225-021-00469-7

11. Katoh K, Standley DM (2013) MAFFT Multiple Sequence Alignment Software Version 7: Improvements in Performance and Usability. Mol Biol Evol 30:772-780. doi:10.1093/molbev/mst010

12. Liu YJ, Whelen S, Hall BD (1999) Phylogenetic relationships among ascomycetes: evidence from an RNA polymerse II subunit. Mol Biol Evol 16:1799-1808

13. Luo Z-L et al (2019) Freshwater Sordariomycetes. Fungal Divers 99:451-660. doi:10.1007/s13225-019-00438-1

14. Rehner SA (2001) Primers for elongation factor 1-alpha (EF1-alpha). http://www.aftol.org/pdfs/EF1primer.pdf

15. Rehner SA, Samuels GJ (1995) Molecular systematics of the Hypocreales: a teleomorph gene phylogeny and the status of their anamorphs. Can J Bot 73:816-823

16. Song $\mathrm{H}-\mathrm{Y}$ et al (2020a) Distoseptispora longispora sp. nov. from freshwater habitats in China. Mycotaxon 135:513-523

17. Song $\mathrm{H}-\mathrm{Y}$ et al (2020b) Westerdykella aquatica sp. nov., producing phytase. Mycotaxon 135:281-292

18. Song H-Y, Hou G-H, Hu D-M (2018a) Dictyosporella hydei sp. nov., an asexual species from freshwater habitats in China. Phytotaxa 358:181-188. doi:http://dx.doi.org/10.11646/phytotaxa.358.2.5

19. Song H-Y, Zhong P-A, Liao J-L, Wang Z-H, Hu D-M, Huang Y-J (2018b) Junewangia aquatica (Junewangiaceae), a new species from freshwater habitats in China. Phytotaxa 336:272-278. doi:10.11646/phytotaxa.336.3.5

20. Stamatakis A, Alachiotis N (2010) Time and memory efficient likelihood-based tree searches on phylogenomic alignments with missing data. Bioinformatics 26:i132-i139. doi:10.1093/bioinformatics/btq205

21. Vilgalys R, Hester M (1990) Rapid genetic identification and mapping of enzymatically amplified ribosomal DNA from several Cryptococcus species. J Bacteriol 172:4238-4246

22. White TJ, Bruns T, Lee S, Taylor JW (1990) Amplification and direct sequencing of fungal ribosomal RNA genes for phylogenetics. In: Innis MA, Gelfand DH, Sninsky JJ, White YJ (eds) PCR Protocols: A Guide to Methods and Application. Academic Press, San Diego, pp 315-322

23. Wu ZH, Wang TH, Huang W, Qu YB (2001) A simplified method for chromosome DNA preparation from filamentous fungi. Mycosystema 20:575-577

24. Yang J, Maharachchikumbura SS, Bhat DJ, Bahkali AH, Jones EG, Liu Z-Y (2015) Aquapteridospora lignicola gen. et sp. nov., a new hyphomycetous taxon (Sordariomycetes) from wood submerged in a freshwater stream. Cryptogamie Mycologie 36:469-478

\section{Figures}




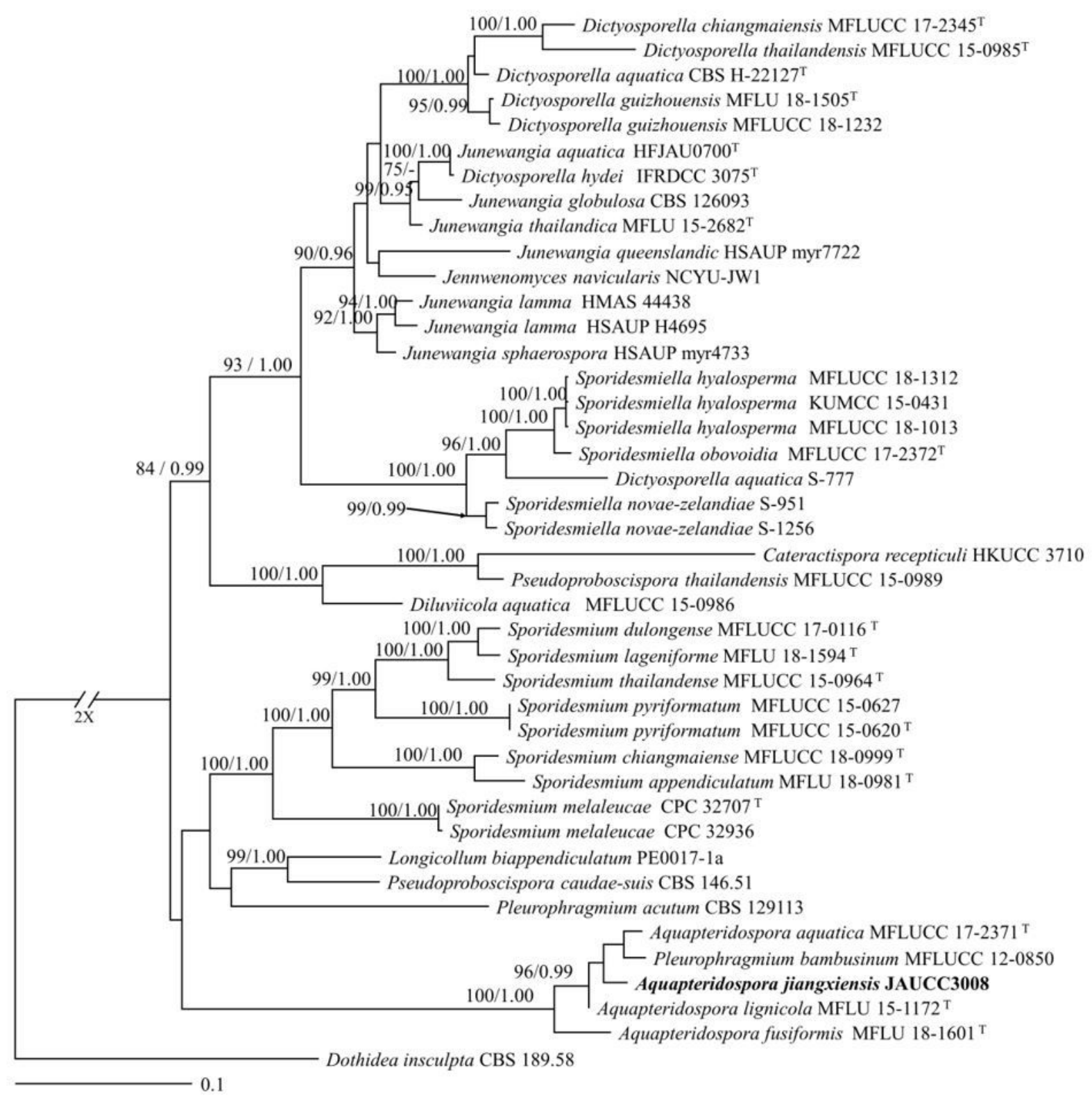

\section{Figure 1}

RAXML tree generated from combined LSU, ITS, SSU, TEF1 and RPB2 sequence data. Bootstrap support values for maximum likelihood equal to or greater than $50 \%$ are placed near the branches The tree is rooted to Dothidea insculpta CBS 189.58. "T" indicate ex-type strains and new species introduced in this study are indicated in bold. 


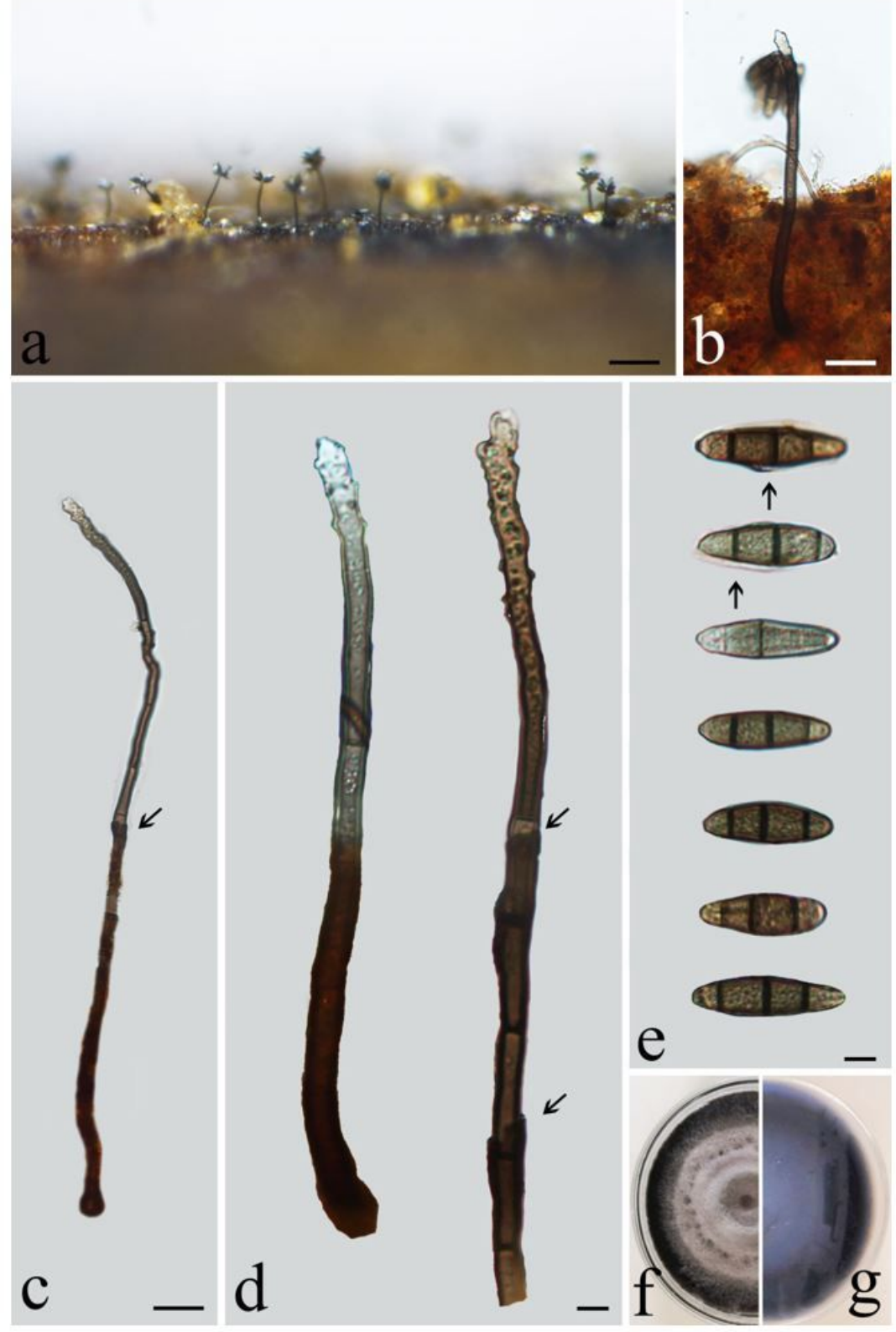

\section{Figure 2}

Aquapteridospora jiangxiensis (HFJAU 3176, holotype). a Colonies on submerged wood. b Conidiophore and conidia. c, d Conidiophores with conidiogenous cells. Note the proliferation (arrowed in c, d). e Conidia. f, g Colony on PDA from above and below. Scale bars: $a=100 \mu \mathrm{m}, \mathrm{b}, \mathrm{c}=20 \mu \mathrm{m}, \mathrm{d}, \mathrm{e}=5 \mu \mathrm{m}$. 